\title{
INTRA AND INTER CLUSTER STUDIES FOR QUANTITATIVE TRAITS IN GARLIC (Allium sativum L)
}

\author{
R. K. Singh ${ }^{*}$, B. K. Dubey and R. P. Gupta \\ National Horticultural Research and Development Foundation, Nashik-422 003, (Maharashtra) India
}

\begin{abstract}
Garlic is propagated vegetatively, the clonal selection is the important breeding method and very scanty work has been done on the association between different traits in garlic. Analysis of variance revealed significant divergence in fifteen garlic clone with checks i. e. Yamuna Safed (G-1), Agrifound White (G-41), Yamuna Safed-2 (G-50) and Yamuna Safed-3 (G-282) for different traits, indicating sufficient genetic diversity among the cultivars. Genotypes belonging to the cluster with maximum inter cluster distance were genetically more divergent. Therefore, it is suggested that based upon large cluster distances to select genotypes from all the clusters, which may lead to broad spectrum of favorable genetic variability for bulb yield improvement. Cluster-III had highest value of plant height $(93.05 \mathrm{~cm})$, bulb diameter $(4.71 \mathrm{~cm})$, bulb size index $\left(16.08 \mathrm{~cm}^{2}\right), 20$ bulb weight $(700 \mathrm{~g})$, clove diameter $(1.75 \mathrm{~cm})$, clove size index $\left(4.43 \mathrm{~cm}^{2}\right)$, weight of 50 cloves $(97.50 \mathrm{~g})$ and gross yield $\left(159.63 \mathrm{t} \mathrm{ha}^{-1}\right)$ and minimum neck thickness $(1.45 \mathrm{~cm})$ number of cloves per bulbs (17) days for bulb initiation (61.66 days) and days to harvesting (149.83). The traits total soluble solids contributed maximum (20.46\%) toward genetic divergence followed by gross yield (16.37\%), bolters $(12.86 \%)$, marketable yield $(11.11 \%)$, number of cloves per bulbs (10.52\%), weight of 50 cloves (10.52\%), days for bulb initiation (10.52\%) and days for harvesting (4.09\%). These traits were considered to be most important for genetic divergence, they contributed (96.45\%) towards genetic divergence and selection of genotypes based on these traits will contribute to wider genetic diversity in the existing gene pool of garlic genotypes.
\end{abstract}

Key words: Garlic, Allium sativum, genetic divergence and $D^{2}$ analysis

\section{INTRODUCTION}

Among the spices grown in India, garlic (Allium sativum L.) is undoubtedly one of the important crops, propagated vegetatively and hence selection and use of

\footnotetext{
* Corresponding author email:singhrknbpgr@yahoo.com
}

Received: 07.03.2013 
diverse parents for its improvement through hybridization is difficult. Garlic consumed by almost all the sections of societies and highly placed for its flavor enhancing capacity and good export potential as fresh bulb as well as in the form of dehydrated product (Gupta and Singh, 1998). Lack of high yielding varieties is one of the main constraints in limiting the production and productivity. Garlic exhibits greater susceptibility to agro-techniques and environmental conditions and possesses a wide range of variability for bulb traits and yield attributes as well as the storability in spite of being vegetatively propagated crop. As this crop is propagated vegetatively, the clonal selection is the important breeding method and very scanty work has been done on the association between different traits which are prerequisite for executing a selection programme. Ministry of Agriculture, India estimate; the annual area under garlic during the year 2012-13 was 2.42 lakh ha and production was 12.28 lakh MT with average yield $5.07 \mathrm{t} \mathrm{ha}^{-1}$. Among different states in India, Madhya Pradesh is the leading state accounting for more than $27 \%$ of area and $21 \%$ of production with average yield of $4.47 \mathrm{t} \mathrm{ha}^{-1}$. The other major garlic growing states are Gujarat, Rajasthan, Orissa, Uttar Pradesh, Maharashtra and Tamilnadu. In India per hectare yield are highest in Kerala $\left(19.0 \mathrm{t} \mathrm{ha}^{-1}\right)$ followed by Manipur (11.91 t ha${ }^{1}$ ), Punjab (10.96 t ha-1), Andhra Pradesh (10.38 t ha' ${ }^{-1}$ ) and West Bengal (9.79 t ha ${ }^{-1}$ ) (Bhonde et al, 2012).

Diversity arises either due to geographical separation or due to genetic barriers to cross ability and it plays an important role in plant breeding. The knowledge of genetic diversity, its nature and degree of variability would be helpful for selecting desirable genotypes and cultivars for a successful breeding programme. Application of this method helps us for maintaining large number of germplasm and avoiding the duplicates. To meet the domestic requirement and fulfill the export demand, selection of suitable variety for growing under different agro-climatic condition is necessary. In this regards National Horticultural Research and Development Foundation (NHRDF), collected more than 400 germplasm from different garlic growing areas. Among of those 19 germplasm were selected including four checks on the basis of yield and yield contributing traits. The present study was therefore, conducted to determine the genetic divergence among 15 selected genotypes along with four checks i. e. Yamuna Safed (G-1), Agrifound White (G-41), Yamuna Safed-2 (G-50) and Yamuna Safed-3 (G-282) and factors influencing genetic diversity and variability of economic traits to identify suitable genotypes of garlic.

\section{MATERIALS AND METHODS}

The experiment was carried out at National Horticultural Research and Development Foundation, (NHRDF) Salaru, Karnal during 2005-06 and 2006-07. Nineteen diverse genotypes including four checks (released varieties) namely Yamuna Safed (G-1), Agrifound White (G-41), Yamuna Safed-2 (G-50) and Yamuna Safed-3 (G-282) (table-1) were evaluated in randomized complete block design with three replications. Uniform size cloves were selected and planted during the first 
fortnight of October in bed of $3.0 \mathrm{~m}$ x $1.5 \mathrm{~m}$ with a spacing of $10 \mathrm{~cm} \times 7.5 \mathrm{~cm}$. The climate of Karnal is subtropical with minimum and maximum temperature ranging between $2^{0}$ to $45^{\circ} \mathrm{C}$ and favorable for garlic cultivation during Rabi season. Recommended dose of chemical fertilizer such as $100 \mathrm{~kg} \mathrm{~N}, 50 \mathrm{~kg} \mathrm{P}_{2} \mathrm{O}_{5}$ and $50 \mathrm{~kg} \mathrm{~K}$ per hectare) were adopted to ensure a healthy crop growth and development. Harvesting was done as per maturity of different genotypes. Observations were recorded on 10 randomly selected plants in each replications for all the characters viz.-plant height $(\mathrm{cm})$, leaves per plant, neck thickness $(\mathrm{cm})$, bulb diameter $(\mathrm{cm})$, bulb size index $\left(\mathrm{cm}^{2}\right)$, weight of 20 bulbs $(\mathrm{g})$, clove diameter $(\mathrm{cm})$, clove size index $\left(\mathrm{cm}^{2}\right)$, cloves per bulbs, weight of 50 cloves (g), bolters (\%), total soluble solid (\%), dry matter (\%), days for bulb initiation, days for harvesting, gross yield ( $\left.\mathrm{t} \mathrm{ha}^{-1}\right)$ and marketable yield $\left(\mathrm{t} \mathrm{ha}^{-1}\right)$.

Pooled data of 2006-2008 were analyzed statistically as suggested by Mahalanobis, (1936). " $\mathrm{D}^{2 \text { " }}$ statistics was used to find out generalized distance between the genotypes as per Rao, (1952). The $\mathrm{D}^{2}$ values were determined to have clustering which was done following Tocher's method. The clusters were grouped in to four divergence classes (DC) on the basis of mean (M) and standard deviation (S).

\section{RESULTS AND DISCUSSION}

On the basis of $\mathrm{D}^{2}$ values, all the 19 genotypes were grouped in three clusters (Table-2). Cluster I was largest consisting of 17 genotypes. Cluster II and III had one genotype each. The genotypes belonging to same status or origin were grouped in to different cluster and the genotypes belonging to different origin were grouped in same cluster. The grouping pattern of the genotypes suggested no parallelism between genetic divergence and geographical distribution of genotypes. Singh et al. (2011), Singh et al, (2012), Lokhande et al. (1987), Mohanty (2001) and Mohanty and Prusti (2002) also reported that genotype diversity was independent of geographical region.

Intra and inter cluster $\mathrm{D}^{2}$ values and corresponding genetic distance are presented in table-3. The highest inter cluster value $\left(\mathrm{D}^{2}\right)$ and genetic distance was noted for cluster-I (852.88), (29.20) while other clusters II and III had zero intra cluster value. Clusters with single genotype (II and III) indicated their independent identity and importance due to various unique characters possessed by them. The intra cluster values were less than inter cluster values indicating the homogenous and heterogeneous nature of the genotypes within and between the clusters. Inter cluster distance $\left(D^{2}\right)$ is the main criterion for selection of genotype. The genotypes belonging to the cluster with maximum inter cluster distance are genetically more divergent. Therefore, it is suggested that selection of genotypes should be based upon large cluster distances, which may lead to broad spectrum of favorable genetic variability for bulb yield improvement. 
Estimates of cluster means for different traits are the measures of inter cluster divergence and degree of homogeneity in these clusters. Cluster mean was worked out and presented in table-4, indicating that the different clusters were superior in respect of various traits.

Cluster-III had highest value of plant height $(93.05 \mathrm{~cm})$, bulb diameter $(4.71$ $\mathrm{cm})$, bulb size index $\left(16.08 \mathrm{~cm}^{2}\right), 20$ bulb weight $(700 \mathrm{~g})$, clove diameter $(1.75 \mathrm{~cm})$, clove size index $\left(4.43 \mathrm{~cm}^{2}\right)$, weight of 50 cloves $(97.50 \mathrm{~g})$ and gross yield $(159.63 \mathrm{t}$ ha-1) and minimum neck thickness $(1.45 \mathrm{~cm})$ cloves per bulbs (17) days for bulb initiation (61.66 days) and days to harvesting (149.83) (Table-3). Cluster-II was promising for highest number of leaves per plant (7.60) and minimum bolters (11.38\%). Cluster I showed highest cloves per bulb (38.57), total soluble solids (38.11\%), dry matter content (40.22\%) and marketable yield (134.89 t ha-1). The largest cluster-I had more and less average values for most of the traits like yield and yield contributory traits. Any attempt to strengthen the existing gene pool with introduction of garlic materials and their evaluation for desirable traits like resistance to insect pest and disease, adoptability, yield and quality is relevant for improving the potentiality of garlic crop.

The characters contributing maximum to the $\mathrm{D}^{2}$ values are to be given greater emphasis for deciding the cluster for the purpose of further selection. The study revealed that total soluble solids contributed maximum $(20.46 \%)$ toward genetic divergence followed by gross yield (16.37\%), bolters (12.86\%), marketable yield (11.11\%), cloves per bulbs (10.52\%), weight of 50 cloves $(10.52 \%)$, days for bulb initiation (10.52\%) and days for harvesting (4.09\%). All above mentioned traits were considered to be most important for genetic divergence and they contributed (96.45\%) towards genetic divergence in this present investigation. Similar findings for contribution towards marketable yield and gross yield were also reported by Khar et al. (2006) in garlic and Mehta et al. (2005) in onion. The result of the present study will help to avoiding duplicates and minimizes the cost of maintenance of garlic germplasm. This also indicates that there is good scope for selection of varieties for desirable traits and cultivation in different part of India for higher productivity.

Therefore it is suggested that based upon large cluster distances to select genotypes from all the clusters, which may lead to broad spectrum of favorable genetic variability for bulb yield improvement.

\section{ACKNOWLEDGEMENT}

The authors are grateful to the Director, National Horticultural Research and Development Foundation, Nashik, for providing necessary facilities during the course of investigation. 


\section{REFERENCES}

Bhonde, S. R., Singh, R. K. and Prakash H. 2012. Garlic cultivation in India. Published by Director, National Horticultural Research and Development Foundation Chitegaon Phata, Post-

Gupta, R. P. and Singh, D. K. 1998. Studies on the performance of different advance lines in garlic, National Horticultural Research and Development Foundation, News letter, 18 (3): 13

Khar, A., Asha, A., Mahajan, V. and Lawande, K. E. 2006. Genetic divergence analysis in elite lines of garlic (Allium sativum L). Journal of Maharashtra Agriculture University 31(1):52-55

Lokhande, G. D., Pawar, B. B., Dumbre, A.D. and Thete, R.Y. 1987. Genetic divergence in garlic (Allium sativum L.). Current Research Report 3: 98-99

Mahalnobis, P. C. 1936. On the generalized distance in statistics. Proc. Nat. Inst. Sci., 12: 4955

Mehta, D. R., Dhaduk, L. K. and Kalathia, K.V. 2005. Genetic variability, diversity, correlations and path coefficient analysis of Indian cultivars of onion under Saurashtra region of Gujrat. In: Singh, U P, Singh, D P \& Sarma, B K (Eds) Recent Advances in Allium Research, Contributory Papers, First National Conference on Alliums 24-25 February 2005, (pp. 128-142). Institute of Agricultural Science Banaras Hindu University, Varanasi

Mohanty, B. K. 2001. Analysis of genetic divergence in Kharif onion. Indian Journal of Horticulture, 58: 260-63

Mohanty, B. K. and Prusti, A. M. 2002. Mahalanobis’s generalized distance analysis in onion. Research on Crops, 3:142-144

Singh, R. K. and B. K. Dubey. 2011. Studies on genetic divergence in onion advance lines. Indian Journal of Horticulture, 68 (1):123-127

Singh, R. K., Dubey B. K. and Gupta, R. P. 2012. Studies on variability and genetic divergence in garlic (Allium sativum L). Journal of Spices and Aromatic Crops, 21 (2): 136-144 
Table 1: Details of genotypes used in experiment and their source of collection

\begin{tabular}{lll}
\hline \multicolumn{1}{c|}{ SN } & \multicolumn{1}{c}{ Genotype } & \multicolumn{1}{c}{ Source of collection } \\
\hline 1 & G-4 & Calcutta, West Bengal \\
2 & G-176 & Rajkot, Gujarat \\
3 & G-189 & NBPGR, New Delhi \\
4 & G-192 & NBPGR, New Delhi \\
5 & G-200 & NBPGR, New Delhi \\
6 & G-222 & NBPGR, New Delhi \\
7 & G-255 & NBPGR, New Delhi \\
8 & G-284 & Mandsaur, Madhya Pradesh \\
9 & G-302 & Rajkot, Gujarat \\
10 & G-304 & IARI, New Delhi \\
11 & G-305 & Karnal, Haryana \\
12 & G-324 & NBPGR, New Delhi \\
13 & G-366 & Indore, Madhya Pradesh \\
14 & G-368 & Dindigul, Tamil Nadu \\
15 & G-369 & Kota, Rajasthan \\
16 & Yamuna Safed G-1(C) & Azadpur, New Delhi \\
17 & Agrifound White G-41(C) & Nalanda, Bihar \\
18 & Yamuna Safed-2 G-50 (C) & Karnal, Haryana \\
19 & Yamuna Safed-3 G-282(C) & Dindigul, Tamil Nadu \\
\hline & &
\end{tabular}

Table 2: Distribution of 19 garlic genotypes in different clusters as obtained by multivariate analysis

\begin{tabular}{c|ccc}
\hline Cluster & Genotypes & Name of genotypes \\
\hline I & \multirow{2}{*}{17} & G-4, G-222, G-176, G-189, G-1, G-284, G-255, G- \\
& & 200, G-304, G-50, G-192, G-41, G-324, G-305, G- \\
II & 01 & G68, G-366, and G-369 \\
III & 01 & G-282 \\
\hline
\end{tabular}


Table 3: Intra and inter cluster $D^{2}$ value and distance $\left(\sqrt{ } D^{2}\right)$ in garlic genotypes

\begin{tabular}{c|c|c|c}
\hline Clusters & I & II & III \\
\hline \multirow{2}{*}{ I } & 852.88 & 2285.42 & 5053.38 \\
& $\mathbf{( 2 9 . 2 0 )}$ & $\mathbf{( 4 7 . 8 1 )}$ & $\mathbf{( 7 1 . 0 9 )}$ \\
II & & 0.00 & 2070.12 \\
& & $\mathbf{( 0 . 0 0 )}$ & $\mathbf{( 4 5 . 5 0 )}$ \\
III & & & 0.00 \\
& & & $\mathbf{( 0 . 0 0 )}$ \\
\hline
\end{tabular}

Table 4: Cluster mean for different traits in garlic genotypes

\begin{tabular}{l|c|c|c|c}
\hline \multirow{2}{*}{\multicolumn{1}{c}{ Characters }} & \multicolumn{3}{|c|}{ Clusters } & \\
\cline { 2 - 4 } & I & II & III & \% Contribution \\
\hline Plant height (cm) & 92.20 & 87.33 & 93.05 & 0.00 \\
Number of leaves/plant & 7.14 & 7.60 & 7.13 & 0.00 \\
Neck thickness (cm) & 1.48 & 1.50 & 1.45 & 0.00 \\
Bulb diameter (cm) & 4.57 & 4.70 & 4.71 & 0.00 \\
Bulb size index (cm ${ }^{2}$ ) & 14.62 & 13.86 & 16.08 & 1.17 \\
Weight of 20 bulbs (g) & 601.47 & 620.00 & 700.00 & 0.00 \\
Clove diameter (cm) & 1.08 & 1.18 & 1.75 & 0.00 \\
Clove size index (cm ${ }^{2}$ ) & 2.70 & 3.06 & 4.43 & 2.33 \\
No. of cloves/bulbs & 38.57 & 25.66 & 17.00 & 10.52 \\
Weight of 50 cloves (g) & 45.80 & 59.66 & 97.50 & 10.52 \\
Bolters (\%) & 17.92 & 11.38 & 15.25 & 12.86 \\
Total soluble solids (\%) & 38.11 & 34.96 & 35.65 & 20.46 \\
Dry matter (\%) & 40.22 & 36.82 & 38.06 & 0.00 \\
Days for bulb initiation & 65.88 & 67.00 & 61.66 & 10.52 \\
Days for harvesting & 158.86 & 151.66 & 149.83 & 4.09 \\
Gross yield (t ha ${ }^{-1}$ ) & 165.57 & 117.28 & 159.63 & 16.37 \\
Marketable yield (t ha ${ }^{-1}$ ) & 134.89 & 81.23 & 122.42 & 11.11 \\
\hline
\end{tabular}

